\title{
ISOLATION AND ANTAGONISM OF BACTERIA TEST OF BIOTA IN THE MANGROVE ECOSYSTEM KAYU ARA RIVER SIAK REGENCY
}

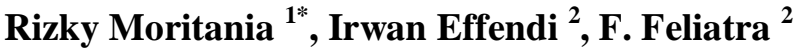 \\ ${ }^{1}$ Student of The Faculty of Fisheries and Marine University of Riau, Pekanbaru \\ ${ }^{2}$ Lecturer at The Faculty of Fisheries and Marine Science University of Riau, Pekanbaru \\ * ririrethania22@gmail.com
}

\begin{abstract}
The General area is the mangrove biodiversity and marine life that have biological activity that likely has the same pharmacological potential as an antimicrobial compound. The purpose of this research is to know the bacterial antagonism in isolation from mangrove, mangrove crabs, snails and fish tembakul against pathogenic bacteria (Aeromonas hydrophila, Aeromonas salmonicida, Edwardsiella ictaluri). This research dimula from May - June 2019. From the results of research that has been done shows that isolates that have the capability of antagonism against pathogenic bacteria test three (A. salmonicida, A. hydrophila and E. ictaluri) were isolate CS7 with category stronger, isolate CS6, CS5, CS4, AI4, AI5, CS9 AI2, with weak category, whereas isolates CS1, B22, B33, B44, AI6 AI7 AI8, was only able to inhibit pathogenic test of 2 with a weak category. The results of the DNA analysis of the 16S rRNA sequence with the use and analysis of BLAST obtained that isolates the Bacillus cereus species are included.
\end{abstract}

Keywords: Mangrove Animals, Antagonism Test, 16S rRNA

\section{PENDAHULUAN}

Kabupaten Siak merupakan salah satu kabupaten yang terdapat di Provinsi Riau yang memiliki salah satu desa yaitu Sungai Kayu Ara dimana merupakan daerah penanaman dan pengembangan kawasan hutan mangrove.Daerah ini merupakan daerah yang berbatasan dengan sungai Siak yang memiliki peran sangat penting dalam mendukung aktivitas masyarakat, terdapat kawasan industri serta pemukiman penduduk.

Adanya aktivitas tersebut dapat menganggu keseimbangan kehidupan biota yang berada di ekosistem mangrove, bahan organik produksi mangrove sebagian besar dimanfaatkan sebagai detritus.Banyaknya bahan organik dapat mempengaruhi distribusi serta aktivitas organisme begitu juga mikroorganisme seperti bakteri.
Keberadaan mikroorganisme tersebut ada yang bermanfaattetapi ada pula yang merugikan misalnya dapat menimbulkan kerusakan akibat kontaminasi yang biasanya disebut bakteri patogen.

Patogen merupakan mikroorganisme sejenis bakteri yang bersifat parasit dan menjadi sumber penyakit bagi inang yang di tumpanginya. Banyak penelitian yang telah dilakukan guna mencegah tersebar nya bakteri patogen penyebab penyakit bakterial pada komunitas budidaya. Salah satunya menggunakan senyawa antimikroba yang diperoleh dari tanaman, hewan maupun senyawa antimikroba buatan. Oleh karena itu penulis tertarik untuk melakukan penelitian tentang isolasi dan uji antagonisme bakteri dari biota di ekosistem mangrove Sungai Kayu Ara Kabupaten Siak. 
Penelitian ini bertujuan untuk mengetahui antagonisme bakteri yang di isolasi dari kepiting bakau, siput bakau dan ikan tembakul tersebut terhadap bakteri patogen (A. hydrophila, A. salmonicida, E. ictaluri).

\section{METODE PENELITIAN}

Penelitian ini telah dilaksanakan mulai dari bulan Mei 2019. Pengambilan sampel dilakukan di ekosistem mangrove Sungai Kayu Ara Kabupaten Siak. Isolasi bakteri dilakukan di Laboratorium Karantina Ikan Pekanbaru. Analisis DNA dilakukan di Laboratorium Genetika Jurusan Biologi, Fakultas Matematika dan Ilmu Pengetahuan Alam.

Metode penelitian ini adalah metode survei, biota mangrove dari ekosistem mangrove Kayu Ara digunakan sebagai sampel untuk identifikasi serta dilakukan uji antagonisme pada 3 bakteri patogen yang berbeda (A.hydrophila, A.salmonicida dan E. ictaluri).

Data yang diperoleh dari hasil disajikan dalam bentuk tabel dan gambar. Data kemudian dibahas secara diskriptif berdasarkan literatur untuk diambil suatu kesimpulan.

\section{Pengambilan Sampel dan Isolasi Bakteri}

Sampel kepiting bakau, ikan tembakul dan siput bakau diambil secara acak sebanyak 5 ekor selanjutnya sampel dimasukkan ke dalam ice box. Bagian organ yang akan diisolasi dari kepiting bakau dan ikan tembakul adalah saluran pencernaan, sedangkan organ yang di isolasi dari siput bakau dimortar terlebih dahulu karena bagian pada siput tidak diketahui. Setelah dilakukan pembedahan organ di tusuk menggunakan jarum ose kemudian digoreskan pada media TSA dengan goresan zig-zag agar pertumbuhan bakteri rata dan tidak terjadi penumpukan pada satu bagian dan di inkubasi selama 24 jam dengan suhu $35^{\circ} \mathrm{C}$ menyesuaikan dengan suhu maksimum perkembangbiakan bakteri.

\section{Identifikasi Bakteri}

Isolat bakteri yang didapat diidentifikasi secara morfologi dan biokimia. Pengamatan morfologi meliputi bentuk koloni, warna koloni, diameter koloni, tepian dan elevasi koloni. Uji biokimia meliputi pewarnaan Gram, uji katalase, uji citrat, uji sulfida, uji motil, uji indol,uji methyl red dan uji TSIA

\section{Uji Antagonisme Bakteri}

Bakteri patogen uji yang telah di murnikan diambil sebanyak $25 \mu \mathrm{L}$ dan diisolasi ke dalam media MHA kemudian di tumbuhkan ke dalam media MHA dengan menggunakan metode sebar. Setelah itu kertas cakram yang telah direndam beberapa menit ke dalam isolat bakteri uji diletakkan ke dalam media MHA tersebut kemudian di inkubasi pada suhu $28^{\circ} \mathrm{C}$ selama 24 jam. Kontrol negatif digunakan kertas cakram yang telah direndam beberapa menit dengan TSB dan untuk kontrol positif digunakan antibiotik tetracylin pada media MHA yang lain. Besarnya aktivitas antibakteri ditentukan dengan cara mengukur diameter zona bening di sekitar cakram.

\section{Uji Molekuler}

Proses isolasi DNA ini terbagi menjadi 5 proses, yaitu perusakaan jaringan, lysis, DNA binding, wash, dan elution. Selanjutnya tahap amplifikasi DNA dilakukan dengan menggunakan PCR (polymerase chain reaction) $50 \mu \mathrm{L}$ dilakukan dengan menggunakan Primer 24 F - 5' - AGA GTT TGA TCC TGG CT - 3' dan $1541 \mathrm{R}$ - 5' - AAG GAG GTC ATC CAE CCG CA - 3' dengan cara template DNA diambil sebanyak $1 \mu \mathrm{L}$ dipindahkan ke dalam tabung berukuran $1 \mathrm{~mL}$ dan dimasukkan $49 \mu \mathrm{L}$ master mix. 


\section{Analisis Sekuen}

Data yang diperoleh dari hasil sequence dianalisis meggunakan teknik BLAST yaitu mencocokkan sequence DNA bakteri yang ada di GenBank .

\section{HASIL DAN PEMBAHASAN Pengamatan Morfologi Koloni}

Hasil pengamatan morfologi koloni bakteri dapat dilihat pada tabel 1 .

Tabel 1. Pengamatan morfologi koloni bakteri

\begin{tabular}{clllll}
\hline Kode Isolat & Diameter & Warna & Bentuk Koloni & Tepian & Elevasi \\
\hline B22 & 1,3 & Putih & Tidak Beraturan & Berlekuk & Datar \\
B44 & 0,9 & Putih & Bentuk L & Berombak & Timbul \\
CS1 & 0,6 & Putih kekuningan & Kompleks & Berlekuk & Datar \\
CS9 & 1,8 & Putih & Tidak Beraturan & Tidak beraturan & Berbukit \\
CS7 & 1,0 & Putih & Bundar & Licin & Timbul \\
CS6 & 2,1 & Putih susu & Bentuk L & Licin & Seperti Kawah \\
CS5 & 1,2 & Putih kekuningan & Tidak Beraturan & Tidak beraturan & Datar \\
\hline
\end{tabular}

Berdasarkan pengamatan morfologi koloni pada Tabel 1, isolat memiliki diameter berkisar antara $0,6-2,1 \mathrm{~cm}$. Isolat yang memiliki warna putih kekuningan, putih dan putih susu. Isolat umumya berbentuk bundar dan tidak beraturan, isolat lainnya berbentuk kompleks, kosentris, bulat, konsentris, bentuk L, bulat dengan tepian timbul dan menyebar. Umumnya tepian koloni tidak beraturan serta elevasi datar.

\section{Uji Biokimia Bakteri}

Hasil pengamatan hasil uji biokimia dapat dilihat pada Tabel 2 .

Tabel 2. Uji Biokimia isolat bakteri

\begin{tabular}{lclcccccc}
\hline Kode & Uji Gram & Bentuk Sel & Katalase & Citrat & Sulfida & Motil & Indol & MR \\
\hline B22 & - & Bulat & + & + & - & - & - & + \\
B44 & - & Batang & - & + & - & + & - & + \\
CS1 & - & Bulat & - & - & - & + & - & + \\
CS9 & - & Batang & - & + & + & + & - & - \\
CS7 & + & Batang & + & + & - & + & - & - \\
CS6 & + & Bulat & - & + & - & + & - & + \\
CS5 & - & Bulat & + & + & - & + & + & + \\
\hline
\end{tabular}

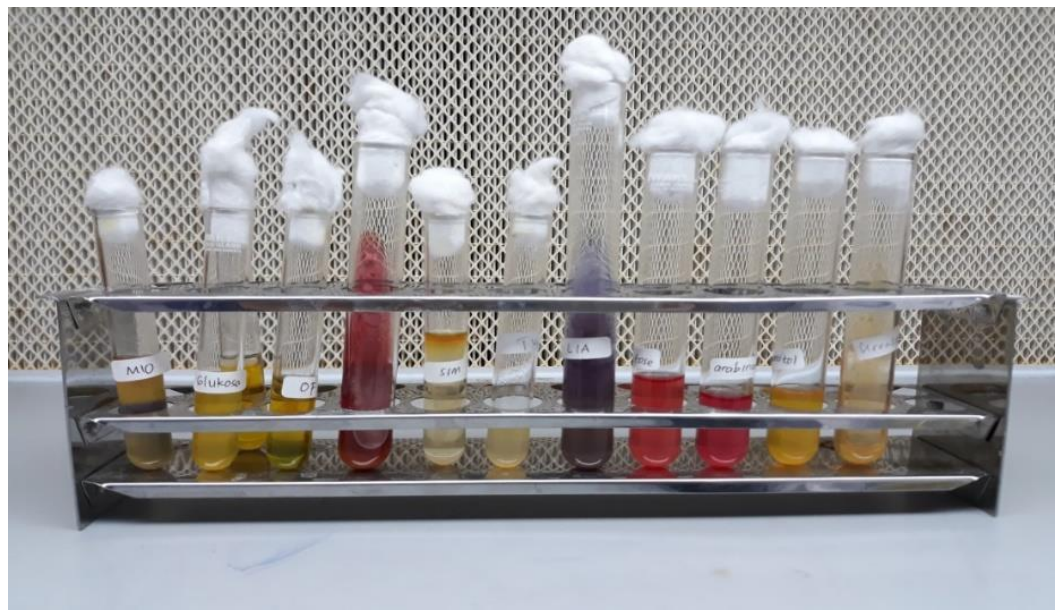

Gambar 1. Uji Biokimia Isolat Bakteri 
Hasil uji biokimia secara umum dapat dilihat pada Tabel 2, hasil uji biokimia menunjukkan bahwa dalam uji Gram terdapat lima isolat Gram negatif dan dua isolat Gram positif. Menurut Safika et al. (2017), Bakteri Gram positif merupakan bakteri yang dapat mempertahankan zat warna violet pada proses pewarnaan Gram. Perbedaan warna didasarkan pada perbedaan struktur dinding sel yang menyusun bakteri. Hasil dari uji katalase menunjukkan empat isolat katalase negatif dan tiga isolat katalase positif. Menurut Samosir et al. (2017), katalase positif bila menghasilkan gelembung udara berarti ada pembentukkan gas oksigen $\left(\mathrm{O}_{2}\right)$ sebagai hasil pemecahan $\mathrm{H}_{2} \mathrm{O}_{2}$ oleh enzim katalase yang diproduksi oleh bakteri tersebut. Hasil uji motil menunjukkan satu isolat motil negatif dan enam isolat motil positif. Menurut Sudarsono dalam Yulvizar (2013), uji positif ditandai dengan pertumbuhan bakteri yang menyebar, menandakan adanya flagella yang berfungsi untuk melakukan pergerakan. Hasil uji sulfida menunjukkan 6 bersifat negatif dan 1 isolat bersifat positif. Uji sitrat menunjukkan isolat bersifat positif dan negatif. Menurut Ulfa et al. (2016), uji sitrat bertujuan mendeteksi kemampuan suatu organisme untuk memanfaatkan sebagai satu-satunya sumber karbon dan energi. Hal ini disebabkan karena penggunaan sitrat oleh bakteri menyebabkan asam menghilang dari biakan sehingga terjadi peningkatan $\mathrm{pH}$ dan mengubah warna media dari hijau menjadi biru. Uji indol menunjukkan satu isolat positif dan enam isolat negatif. Jika Terbentuk lapisan cincin berwarna merah pada permukaan biakan, artinya bakteri ini membentuk indol dari triptophan sebagai sumber karbon (Widyawati, 2012). Uji methyl red menunjukkan dua isolat bersifat negatif dan lima bersifat positif. Uji methyl red bertujuan untuk mendeteksi kemampuan organisme dalam memproduksi dan mempertahankan produk akhir asam stabil dari fermentasi glukosa. Methyl Red adalah indikator $\mathrm{pH}$ dengan hasil positif berwarna merah (Rahayu dan Gumilar, 2017).

\section{Uji Penggunaan Gula}

Hasil pengamatan hasil uji penggunaan gula dapat dilihat pada Tabel 3 .

Tabel 3. Uji Penggunaan Gula terhadap Isolat Bakteri

\begin{tabular}{cccc}
\hline Kode & Glukosa & Laktosa & Sukrosa \\
\hline B22 & + & + & + \\
B44 & + & - & - \\
CS1 & + & + & + \\
CS9 & + & + & + \\
CS7 & - & + & - \\
CS6 & - & + & + \\
CS5 & + & + & + \\
\hline
\end{tabular}

Hasil uji penggunaan gula menunjukkan empat isolat mampu memfermentasi ketiga gula yaitu glukosa, laktosa dan sukrosa, satu isolat hanya mampu memfermentasi glukosa, satu isolat hanya mampu memfermentasi laktosa dan sukrosa dan satu isolat lainnya tidak mampu memfermentasi ketiga gula tersebut. Fardiaz dalam Wahyuni (2018), bahwa warna merah pada agar menunjukkan reaksi basa, sedangkan warna kuning menunjukkan reaksi asam.

\section{Uji Antagonisme Bakteri}

Hasil pengamatan hasil uji antagonisme bakteri dapat dilihat pada Tabel 4. 
Tabel 4. Uji Antagonisme Isolat Bakteri

\begin{tabular}{|c|c|c|c|}
\hline Nama & \multicolumn{3}{|c|}{ Rata-rata Diameter Zona Hambat (mm) } \\
\hline Kode Isolat & A. hydrophila & A. salmonicida & E. Ictaluri \\
\hline CS7 & 18,6 & 21 & 19,6 \\
\hline CS6 & 3,5 & 2,3 & 1,3 \\
\hline CS5 & 2,8 & 2,2 & 1 \\
\hline CS9 & 3,3 & 5 & 1,8 \\
\hline CS1 & 0 & 4,8 & 0 \\
\hline B44 & 4,3 & 0 & 1,8 \\
\hline B22 & 0 & 0 & 0 \\
\hline
\end{tabular}

Berdasarkan nilai rata-rata zona bening yang terbentuk dapat dilihat bahwa isolat bakteri CS7 sampai dengan B22 memiliki kemampuan yang berbeda dalam menghambat pertumbuhan dari bakteri $A$. salmonicida, A. hydrophila, dan E. ictaluri. Uji antagonisme isolat bakteri terhadap patogen $A$. hydrophila nilai rata-rata zona bening terbesar adalah isolat CS7 sebesar $18,6 \mathrm{~mm}$ dan yang terkecil adalah isolat B22 dan CS1.

Isolat CS7 memiliki respon hambat terbesar terhadap bakteri patogen $A$. hydrophila, yaitu dengan diameter rata-rata zona bening $21 \mathrm{~mm}$ dan memiliki respon daya hambat terkecil terhadap bakteri patogen $A$. salmonicida yaitu dengan diameter rata-rata zona bening 18,6 $\mathrm{mm}$. Sedangkan isolat lain memiliki respon hambat yang lemah karena memiliki nilai diameter $<5 \mathrm{~mm}$. Menurut Davis dan Stout dalam Mahmudah dan Sri (2017), menjelaskan bahwa klasifikasi respon hambatan pertumbuhan bakteri yang dilihat berdasarkan diameter zona bening terdiri atas empat kelompok yaitu respon lemah (diameter $\leq 5 \mathrm{~mm})$, sedang (diameter 5-10 $\mathrm{mm}$ ), kuat (diameter 10-20 $\mathrm{mm}$ ), dan sangat kuat (diameter $\geq 20 \mathrm{~mm}$ ).

Berdasarkan hasil uji antagonisme yang dilakukan, isolat bakteri yang diisolasi dari biota memiliki respon hambat dengan diameter yang berbeda diukur dari adanya zona bening disekitar kertas cakram. Menurut Adithya (2017), hasil yang berbeda disebabkan oleh kemampuan setiap bakteri dalam melawan aktivitas antibakteri tergantung dari ketebalan dan komposisi dinding selnya dan disebabkan oleh perbedaan kandungan metabolit sekunder yang dimiliki oleh masing masing isolat yang telah berdifusi terlebih dahulu ke dalam agar, sehingga pertumbuhan bakteri patogen menjadi terhambat.

\section{Analisis Sekuens}

Berdasarkan hasil anilisis BLAST dengan merujuk pada Gen Bank melalui situs http://www.ncbi.nlm.nih.gov menunjukkan bahwa isolat CS7 memiliki nilai homologi 99,29\% terhadap Bacillus cereus yang tertera pada Tabel 5.

Tabel 5. Analisis BLAST Isolat Bakteri

\begin{tabular}{lllll}
\hline No & Spesies & Strain & Kode Akses & Homologi \\
\hline 1 & B. cereus & BCT-7112 & $\underline{\text { NR121761 }}$ & $99,29 \%$ \\
2 & B. toyonensis & FSLW8 & $\underline{\text { NR 152692 }}$ & $99,59 \%$ \\
3 & B. marcorestinctum & LQQ & $\underline{\text { NR 117414 }}$ & $98,79 \%$ \\
4 & B. bingmayongensis & FJAT-13831 & $\underline{\text { NR 148248 }}$ & $99,08 \%$ \\
5 & B. gaeomokensis & BL3-6 & $\underline{\text { NR 116644 }}$ & $98,61 \%$ \\
6 & B. manliponensis & BL4-6 & $\underline{\text { NR 125530 }}$ & $98,04 \%$ \\
7 & B. solisislvae & NEAU & $\underline{ }$ & $94,13 \%$ \\
\hline
\end{tabular}


Jika dilihat dari tingkat homologinya berarti isolat CS7 dapat mewakili pada tingkat spesies yang sama, hal ini sesuai dengan pendapat Hagstrom et al. dalam Feliatra et al. (2011) menyatakan bahwa isolat yang mempunyai persamaan homologi lebih dari $97 \%$ dapat mewakili pada tingkat spesies yang sama. Persamaan homologi antara 93\% - 97\% dapat mewakili identitas pada tingkat genus tetapi berbeda pada tingkat spesies, jika dibawah 93\% kemungkinan spesies baru yang urutan basa nitrogennya belum masuk dalam database Genbank.

Berdasarkan hasil dari identifikasi secara morfologi dan biokimia, menunjukkan bahwa isolat bakteri CS7 termasuk ke dalam genus Bacillus koloni bakteri berwarna putih susu, bentuk koloni bundar dengan tepian licin dan elevasi timbul merupakan bakteri Gram positif, bersifat motil, indol negatif dan katalase positif. Pernyataan ini didukung oleh Bottone (2010) bakteri Bacillus cereus merupakan bakteri Gram positif bersifat motil oval, kadang-kadang bundar atau silinder dan sangat resisten pada kondisi yang tidak menguntungkan. Bakteri ini bersifat aerobik sampai anaerobik fakultatif, katalase positif dan merupakan bakteri gram positif berbentuk batang katalase positif, indol negatif dan mampu memfermentasi glukosa serta laktosa dan sukrosa.

Bacillus cereus adalah bakteri berbentuk batang yang berspora dan bersifat gram positif, selnya berukuran besar dibandingkan dengan bakteri batang lainnya suhu pertumbuhan maksimum 37$48^{\circ} \mathrm{C}$ dan minimum $5-20^{\circ} \mathrm{C}$ dan $\mathrm{pH}$ pertumbuhan 5,5-8,5 serta tumbuh secara aerob fakultatif, juga memfermentasi karbohidrat. Habitat utama B. cereus adalah lingkungan dan saluran pencernaan. Terutama tanah dan air (Nurwidiani, 2010). Menurut Pananjung et al. (2015) bakteri dari jenis ini tidak hanya dijumpai di tanah, air, makanan fermentasi tetapi juga ditemukan di perairan pantai.

Berdasarkan uji antagonisme isolat CS7 mampu menghambat pertumbuhan ketiga bakteri patogen uji yakni $A$. hydrophila, A. salmonicida dan E. ictaluri dengan kategori kuat, hal ini dapat dilihat adanya zona bening dengan diameter $>10$ $\mathrm{mm}$ pada saat uji antagonis. Kemampuan ini diduga karena bakteri dari jenis ini menghasilkan senyawa antibiotik. Senyawa antibiotik merupakan kumpulan zat-zat kimia yang diproduksi oleh mikroorganisme baik fungi maupun bakteri yang memiliki fungsi menghambat pertumbuhan atau membunuh organisme lain. B.cereus memberikan respon positif yaitu, terbentuknya hambatan yang terjadi pada pertumbuhan bakteri Aeromonas sp dan vibrio sp, respon ini terlihat dengan terbentuknya zona yang terputus oleh adanya pertumbuhan bakteri B.cereus (Feliatra, 2011). Kemampuan bakteri B.cereus dalam menghambat atau menginterupsi bakteri patogen belum dipastikan apakah karena dapat mematikan atau menghasilkan antibiotik yang dapat menurunkan populasi bakteri patogen secara keseluruhan.

Menurut Prangdimurti dalam Feliatra (2012), antagonisme ada dua macam yaitu antagonisme sejati dan antagonisme vektor. Antagonisme sejati terjadi jika suatu organisme benar-benar menghambat organisme lainnya, sedangkan antagonisme vektor terjadi jika suatu jenis bakteri menghambat bakteri lain secara aktif karena makanan dan kehidupan yang terbatas

\section{KESIMPULAN DAN SARAN Kesimpulan}

Berdasarkan hasil penelitian yang telah dilakukan menunjukkan bahwa isolat yang memiliki kemampuan antagonisme terhadap tiga bakteri patogen uji (A.salmonicida, A.hydrophila dan E.ictaluri) adalah isolat CS7 dengan 
kategori kuat, isolatCS6, CS5, CS9, dengan kategori lemah, sedangkan isolat B44, B22 hanya mampu menghambat 2 dari patogen uji dengan kategori lemah. Hasil analisis DNA dengan menggunakan sekuens 16SrRNA didapatkan bahwa isolat tersebut termasuk spesies B. cereus.

\section{Saran}

Penelitian selanjutnya disarankan perlu dilakukan penelitian lanjutan berupa uji tantang lapangan terhadap ikan sebagai sampel uji dengan patogen yang berbeda.

\section{DAFTAR PUSTAKA}

1. Adithiya, D.S., Feliatra., dan A, Tanjung. (2017). Penggunaan Bakteri Heterotrofik sebagai Antibakteri terhadap Bakteri Patogen yang diisolasi dari Perairan Laut Kota Dumai.

2. Bottone, E. J. (2010). Bacillus cereus, a volatile human pathogen, Clinical Microbiologi Reviews, Volume 23 (2), Pages 382-398.

3. Feliatra, F. T.Nogroho, T. Silalahi, dan S. Y. Octavia. (2011). Skrining Bakteri Vibrio Sp Asli Indonesia sebagai Penyebab Penyakit Udang Berbasis Tehnik 16S Ribosomal DNA. Jurnal Ilmu dan Teknologi Kelautan Tropis. Volume 3 (2), Pages 85-99.

4. Feliatra, Y. Fitria, dan Nursyirwani. (2012). Antagonis Bakteri Probiotik yang diisolasi dari Usus dan Lambung Ikan Kerapu Bebek (Cromileptes Altivelis) Terhadap Bakteri Patogen. Jurnal Perikanan dan Kelautan, Volume 17(1), Pages 16-25.

5. Mahmudah, F. L., dan A. Sri. (2017). Uji Aktivitas Antibakteri dari Ekstrak Ethanol Temukunci Terhadap Bakteri Streptococcus mutan. Jurnal Penelitian Saintek. Volume 22(1), Pages 22-28

6. Nurwidiani. (2010) .Verifikasi Metode Uji Bacillus cereus pada Sampel Uji Bumbu dan Bahan Makanan.

7. Pananjung, A. M. S., E. U. Ulfa., K. Senjarini., S. Arimurti. (2015). Karakterisasi Isolat Bakteri Fibrinolitik Wu 021055 Asal Perairan Pantai Papuma, Jember. Jurnal Bioteknologi dan Biosains Indonesia. Volume 2(1), Pages 1-8

8. Safika. (2017). Total Colony Bacteria Cellulolitic in The Rumen of Aceh Cattle. Jurnal Medika Veterinaria. Volume 11(1), Pages 51-58.

9. Samosir, M. F., D. Suryanto, dan Desrita. (2017). Isolasi dan Identifikasi Bakteri Potensial Probiotik pada Saluran Pencernaan Ikan Mas (Cyprinus carpio). Jurnal Biologi Volume 6(2), Pages 61-65.

10. Ulfa, A., E. Suarsini, dan M. H. I. A. Muhdar. (2016). Isolasi dan Uji Sensitifitas Merkuri pada Limbah Penambangan Emas di Sekokotong Barat Kabupaten Lombok Barat Penelitian Pendahuluan. Proceeding Biologi Education Conference.Volume 13(1), Pages 797.

11. Wahyuni. R, M., A. Sayuti., M. Abrar., Erina dan Zainuddin. (2018). Isolasi dan Identifikasi Bakteri Enterik Patogen pada Badak Sumatera (Dicherorhinus sumatrensis) di Suaka Rhino Sumatera (SRS) Taman Nasional Way Kambas (TNWK) Lampung. Jurnal Kedokteran Hewan. Volme 2 (4), Pages 474-487.

12. Widyawati, R. (2012). Penuntun Praktek Mikrobiologi, Uji IMViC. http://rodiahmikrobiologi.blogspot.com/2012/ 01/uji-imvic.html. Tgl: 18 juni 2019.

13. Yulvizar, C., (2013). Isolasi dan Identifikasi Bakteri Probiotik pada Rastrelliger sp. Skripsi. Indonesia: Universitas Syiah Kuala. Volume 6(2), Pages 1-7. 